\title{
Identification of circulating MOG-specific B cells in patients with
}

\section{MOG antibodies}

Neurol Neuroimmunol Neuroinflamm 2020;7:e647. doi:10.1212/NXI.0000000000000647

In the article "Identification of circulating MOG-specific B cells in patients with MOG antibodies" by Winklmeier et al., ${ }^{1}$ first published online October 14, 2019, on the right side panel in figure 2a, the labelling of patient 15 should not have been included while the labelling of patient $26 \mathrm{~b}$ should have been included. The corrected figure appears below. The publisher and the authors regret the error.

Figure
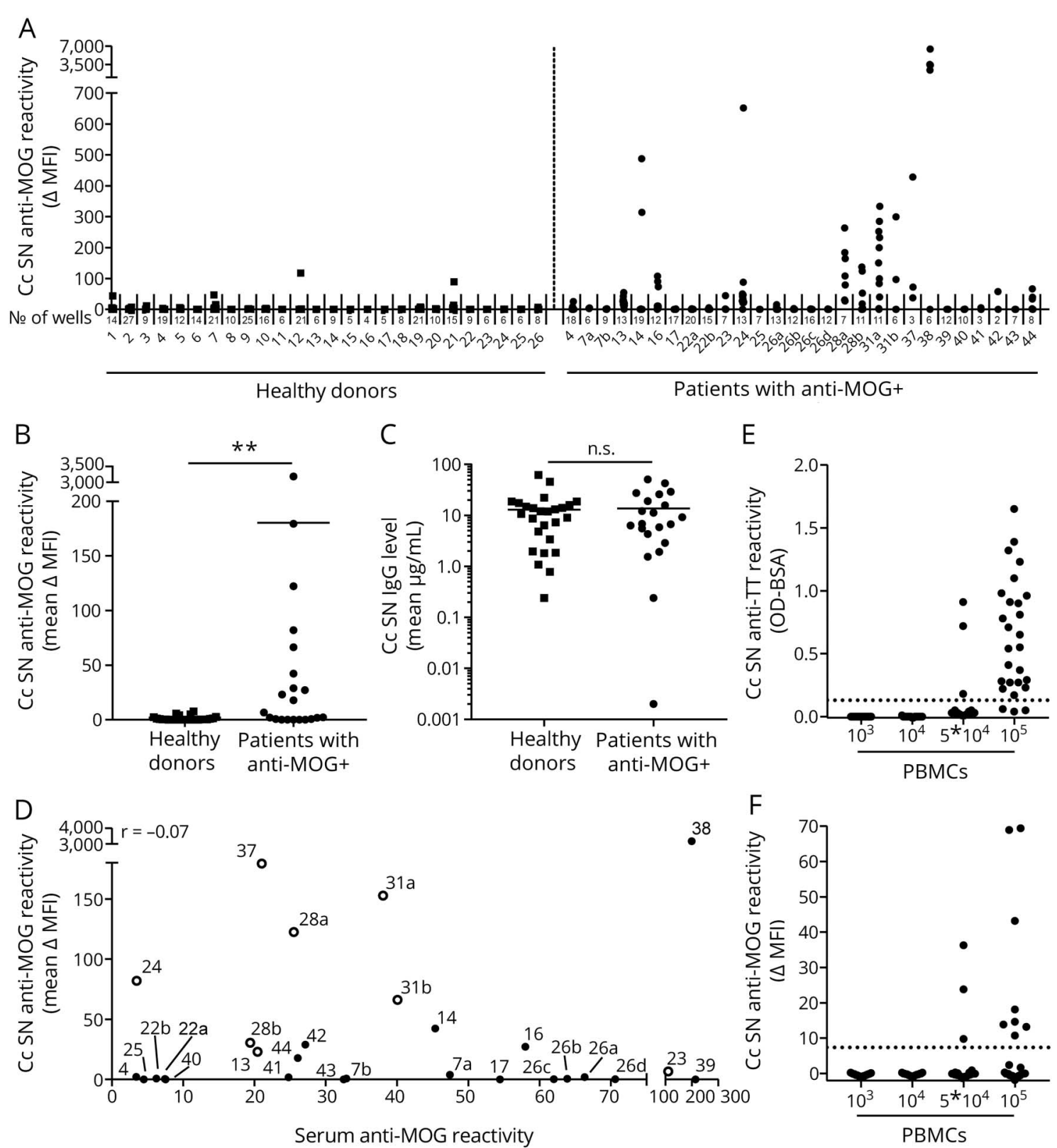

Serum anti-MOG reactivity

(MFI ratio)

\section{Reference}

1. Winklmeier S, Schlüter M, Spadaro M, et al. Identification of circulating MOG-specific B cells in patients with MOG antibodies. Neurol Neuroimmunol Neuroinflamm 2019;6:e625. doi: 10.1212/NXI.0000000000000625. 


\section{Neurology \\ Neuroimmunology \& Neuroinflammation}

\section{Identification of circulating MOG-specific B cells in patients with MOG antibodies \\ Neurol Neuroimmunol Neuroinflamm 2020;7; \\ DOI 10.1212/NXI.0000000000000647}

This information is current as of November 15, 2019

\section{Updated Information \& Services}

References

Subspecialty Collections

Permissions \& Licensing

Reprints including high resolution figures, can be found at: http://nn.neurology.org/content/7/1/e647.full.html

This article cites 1 articles, 0 of which you can access for free at: http://nn.neurology.org/content/7/1/e647.full.html\#\#ref-list-1

This article, along with others on similar topics, appears in the following collection(s):

All Clinical Neurology

http://nn.neurology.org//cgi/collection/all_clinical_neurology

All Immunology

http://nn.neurology.org//cgi/collection/all_immunology

All Neuro-ophthalmology

http://nn.neurology.org//cgi/collection/all_neuroophthalmology

Optic neuritis; see Neuro-ophthalmology/Optic Nerve

http://nn.neurology.org//cgi/collection/optic_neuritis

Information about reproducing this article in parts (figures,tables) or in its entirety can be found online at:

http://nn.neurology.org/misc/about.xhtml\#permissions

Information about ordering reprints can be found online:

http://nn.neurology.org/misc/addir.xhtml\#reprintsus

Neurol Neuroimmunol Neuroinflamm is an official journal of the American Academy of Neurology.

Published since April 2014, it is an open-access, online-only, continuous publication journal. Copyright $(\subset$ 2019 American Academy of Neurology. All rights reserved. Online ISSN: 2332-7812.

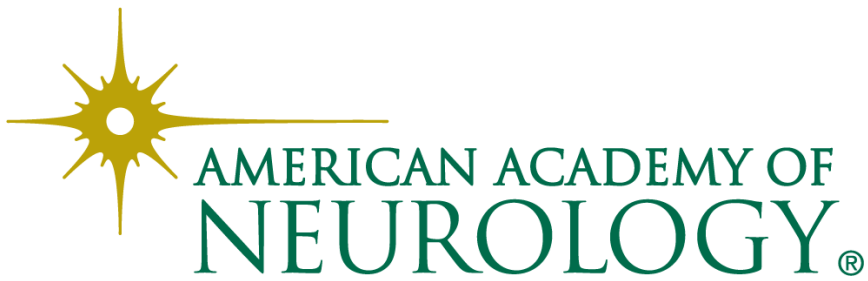

